scribe a number of Scandinavian antiquities found at York. Dr. L. R. Farnell, in a communication on the development of Greek religion, will criticise Dr. Usener's theories concerning Sondergötter and Augenblick-Götter. Among the communications in general ethnography may be mentioned :--Education and evolution, the Rev. A. E. Crawley; a paper by Messrs. T. A. Joyce and E. Torday on the ethnography of the south-west Congo Free State, dealing with the migrations of the inhabitants of the territory drained by the Kwango and Kwilu Rivers; a paper by Dr. W. H. R. Rivers on Morgan's Malayan system of relationship, which adduces evidence against his concept of the "consanguineous family" as the earliest stage of the development of human society. Prof. R. J. Anderson, in a paper on racial types of Connaught, describes the chief physical types of that province, and discusses the chief influences by which they are, or have been, modified; a study of the condition of the Maoris in r 907 , by Miss B. Pullen-Burry, after describing their religion and social organisation, deals with their economic and social condition. Among papers of a technical character, considerable interest attaches, in view of the present lack of agreement as to the use of anthropological terms, to a communication by $\mathrm{Dr}$. Rivers in which he attempts to define the use of certain sociological terms, and to a communication by Mr. J. L. Myres on the use of the triangle in decorative art.

The provisional programme of Section I (Physiology) is as follows:-August I : Presidential address and miscellaneous papers. The president, Dr. A. D. Waller, has been studying chloroform of late, and his address will probably take the form of a general statement on, the position of anæsthetics at the present time. August 2: The morning will be devoted to papers on the electrophysiology of animals and plants. Dr. Alcock, Dr. Waller, and others will read papers. August 5: A discussion on the physiological and therapeutical uses of alcohbl' will be opened by Prof. Cushny. Other speakers will include Sir Victor Horsley, Dr. Dixon, Dr. Rivers, and Dr. Waller. August 6: A discussion on antitoxins will be opened by Prof. Sims Woodhead. The afternoons will be in part given to the reading of reports. There are three committees. which should report, the subjects being :-(I) The investigation of the effect of climate upon health; Sir Lauder Brunton, the president of this committee, will read the report; (2) the determination of the metabolic balance-sheet of the individual tissues, president, Prof. Gotch; (3) the ductless glands, Prof. Schäfer. These reports will be presented on the afternoons of August 1, 2, and 6 respectively.

In Section K (Botany), Miss Fraser (of the Royal Holloway College) and others will communicate the results of recent investigations on the cytology of fungi, particularly in relation to sexuality and the reduction division. Mr. V. H. Blackman will take part in the discussion on this subject. Prof. F. O. Bower will communicate the results of his recent work on the embryos of Pteridophytes. Prof. Conwentz, the Prussian State Commissioner for the preservation of natural monuments, will deliver a lecture, illustrated bv lantern slides, at a joint meeting of Sections C, E, and K, on the care of natural monuments. Prof. F. W. Oliver is expected to communicate the results of some recent investigations of Palæozoic seeds. Prof. Weiss will give the semi-popular lecture on pollination in recent and fossil plants. 'There will be a joint meeting with Section $D$ 'to discuss the physical basis of heredity (opened by Prof. Hickson), and with Sections $\mathrm{D}$ and $\mathrm{L}$ to discuss the teaching of botany in schools. Prof. Armstrong will communicate a paper on the theory of enzyme-action. There will be a visit to Mr. Hurst's nurseries at No. I967, voL. 767
Burbage to inspect his experiments in hybridisation, and a botanical excursion to Charnwood Forest.

Discussions on several important subjects have been arranged by the organising committee of Section L (Educational Science); and among the authors and speakers are leading representatives of every grade of educational activity. The chief educational associations have appointed delegates to attend the meeting. After Sir Philip Magnus's presidential address on August I, there will, be a discussion at a joint meeting with Section $H$ (Anthropology) on anthropometrics in schools; with particular reference to the recommendations of the Physical Deterioration Committee. Among the expected speakers are Sir Victor Horsley, Mr. R. C. Lehmann, M.P., Dr. F. C. Shrubsall, Mr. J. Gray, Mr. E. Meyrick, Prof. M. E. Sadler, Dr. J. Gow, Mr. Cecil Hawkins, and Mr. S. R. Brown. Friday, August 2, will be occupied with a discussion of the scholarship system in all its aspects from the primary school to the university, with papers by Miss J. Cleghorn, Mr. A. R. Pickles, president of the National Union of Teachers; Mr. W. A. Brockington, Miss S. Heron, Mr. J. L. Paton, Mr. G. Gidley Robinson, Rev. A. A. David, Dr. H. B. Baker, Prof. H. A. Miers, and Prof. M. E. Sadler. The curricula of secondary schools will form the subject of discussian on the morning of August 5, in connection with the report of a committee appointed at the York meeting last year. Mr. R. E. Thwaites will state the results of an inquiry into science teaching in secondary schools. In the afternoon there will be a joint meeting with Sections $D$ and $K$ on the teaching of biology in schools, to be introduced bv Mr. O. $\mathrm{H}$. Latter. Other speakers will be Prof. S. J. Hickson, Prof. J. B. Farmer, Miss Lilian Clarke, Miss Laurie, Mr. M. D. Hill, Mr. E. Meyrick, and Mr. Hugh Richardson. August 6 will be devoted to scientific teaching in relation to trade classes and industrial requirements, this general description to include the consideration of domestic subjects in girls' schools, day trade schools for girls, preparation for technical training in day and evening schools, and the qualifications of teachers. Papers dealing with these subjects will be contributed by Mrs, Ramsay MacDonald, Mr. C. T. Millis, Mr. J. G. Legge, and Mr. J. H. Hawthorn.

\section{THE KING AND HIGHER EDUCATION IN WALES.}

T HE foundation stone of the new buildings of the University College of North Wales was laid by the King on Tuesday, July 9. The King was accompanied by the gueen, and the ceremony was performed in the presence of a large and brilliant assembly. In his response ty an address of welcome, presented by the Lord Liejatenant, the King said that the main object of his fisit to Wales was to express again his belief in the necessity of affording the youths of the country the most complete educational equipment possible, both for their self-improvement and in order to enable them to acquire success in life. The King also remarked, in the course of a reply to an address presented by the Mayor and Corporation of Bangor, that "Education, and especially secondary education, is a subject the importance of which cannot be over-estimated, and which engages my cordial interest and encouragemen." Peplying on behalf of the Queen and himself to an address from the governors of the college, the King again referred to his interest in higher education in the following words -

The admirable wurk performed by the college in its temporary juildings has been widely recognised and was 
well known to me when I held the office of Chancellor of the University of Wales. I feel confident that increased efficiency will result from the facilities afforded by the commodious premises of which I have to-day laid the first stone. The competition in every branch of industry, especially in those branches which depend largely on science and art, is in these days severe, and it must be met by increased application and improved methods. The world is, I believe, better for such competition, but it behoves individual nations to use every possible effort to hold their own in the struggle. For this purpose higher education is an absolute necessity. However brilliant a man's natural talents may be, he is greatly hindered by the want of early training, and as a rule only those who have enjoyed a good education are capable of acquiring such proficiency in any branch of study as will enable them to succeed. The University College of North Wales will offer to its students exceptional opportunities of instruction. Time and money, energy and perseverance, will, I am sure, not be spared in the endeavour to afford every facility to the acquirement of knowledge, and I have had sufficient opportunities of judging the intelligence of the Welsh people and their eagerness in the pursuit of knowledge to know that your young men and women will take every advantage of the instruction which is offered them.

At the close of the ceremony of laying the foundation stone, the King conferred the honour of knighthood upon Dr. H. R. Reichel, the principal of the college.

\section{NOTES.}

WE regret to anpounce that Sir William $H$. Broadbent, Bart., F.R.S., fhysician in ordinary to the King and to the Prince of yales, died on Wednesday, July 10, at seventy-two years of age.

THE Vettleship gold medal of the Ophthalmological Society of the United Kingdom has been awarded to Dr. Je Herbert Parsons, for his work on "The Pathology of the Eye."

THE counct of the Institution of Civil Engineers has appointed Sir William Matthews, K.C.M.G., president of that institution, to succeed the late Sir Benjamin Baker, K.C.B., K.C.M.G., as one of their representatives on the main committee of the Engineering Standards Committee.

THE annual meeting of the Victoria Institute will be held at Burling House, Piccadilly, on Wednesday, July 17 . The chair will be taken by the president, the Earl of Halsburf, F.R.S. ; and an address will be given by Bishop Welldor.

THE Women's Agricultural and Horticultural International Union will hold an exhibition and sale of farm and garden froduce, and of nature-study teaching apparatus, in/the gardens of the Royal Botanic Society, Regent's Parky on Wednesday, July i7. For the convenience of tedchers, the nature-study room will be kept open until Saturday, July 20.

THE vacarcy in the tidal and optical departments of the National Phyșical Laboratory, occasioned by the appointment of Mr. J. de Graaf Hunter to the post of matheyatical expert on the Indian Survey, has been filled by the appointment of Mr. T. Smith, formerly scholar of Queens' College, Cambridge.

THE recent death of $M$. Charles Tupied, director of the Algiers. Observaty inflicts another severe loss on the rankg of frend a thomers. In the organisation of the pork of the Astrographic Catalogue and Chart he play a an Getere and prominent part from the beginning, and it is to be deplored that he was not spared to see the colmpletion of his labours. M. Trépied became director of NO. 1967 , VOL. 76$]$ the observatory at Algiers in 1880 , anc ir. the following year carried out a scheme of reorganisation. In $188_{3}$ the observatory was removed from its temporary site at Kouba to its present position at Bondzavéah, eleven kilometres from Algiers, and was further equipped with an equatorial coude, and later with a photographic instrument of the standard photographic pattern. Since 1875 M. Trépied was a prolific writer on all branches of astronomy, and gave much study to the physical condition of the sun and to cometary spectra, while the observatory under his charge was always most.active in observational work of all kinds. On the occasion of the solar eclipse of 1900 , he extended the most generous hospitality and assistance to the foreign astronomers who visited Algiers. $\mathrm{He}$ was a corresponding member of the Paris Academy of Sciences.

Prof. W. J. Sollas, F.R.S., professor of geology and palæontology at Oxford, and his assistant, Mr. M. Allorge, have just taken the geological class to Belgium to study the structure of hat country. In the Easter expedition of the students Dr. Vaughan and Prof. Reynolds explained the zoning of the Carboniferous limestone in the Bristol district; and the object of the present expedition is to bring the res/lts then obtained into comparison with the facts furnished by the Belgian limestones. The leading Belgian geologists, MM. Mourlon, Gosselet, Halet, Simoens, Lohest, Formarié, and Rutot, are acting as guides for the various visits and excursions which have been arranged. The expedition thus provides facilities for geological observations under the best conditions.

THE retirement is announced of Prof. G. Lunge, at the age of sixty-eight, from the chais of technical chemistry at Zurich, a position which he held during the past thirty-one yeare Pfof wange's name is intimately associat $/ d$ wit the depment of chemical industry in Germaty not of on account of the influence he exerted on hi Many students, but more directly owing to his inventions and treatises on applied chemistry. At the time when he, as a young man, completed his studies at Heidelberg, chemical industry had hardly come into existence in Germany, so that in order to gain practical experience he found it necessary to proceed to England. In this country, in which he spent the twelve years 1864 1876 , he was first actively engaged in studying the problems connected with the distillation of coal tar, but subsequently acted as manager of a large soda works at Tyneside. He was one of the founders of the Newcastle Chemical Society, a precursor of the Society of Chemical Industry. In 1876 Prof. Lunge received a call to the professorship of technical chemistry at Zurich, a position which, in spite of many inducements to pass to other universities, he continued to occupy until this year. His books on coal-tar distillation and on the manufacture of acid and alkali have, since the publication of the first volume in 1879 , become almost classics in chemical technology.

AN influentially signed appeal was published in the Times of July 5 for donations to a fund which is being raised to ensure the preservation of characteristic examples of the "grey wotiers" on Marlborough Downs. These boulders are loghly known as "Sarsen Stones," and are geologically the sand formerly cofering the chalk which in the course of time has been denuded of the softer portions. For many generations these stones have been broken up and used for building and other purposes, but the breaking up has not been on such a scale as to make any appreciable difference in the appearance of the downs. A recent 